\title{
MEDZINÁRODNÁ ADMINISTRATÍVNA SPOLUPRÁCA V OBLASTI DPH
}

\section{Pavel Kaštánek*, Katarína Isteníková*}

Medzinárodná administratívna spolupráca je efektívnym nástrojom boja proti daňovým podvodom a vyhýbaniu sa plateniu daní a to predovšetkým v podmienkach globalizácie svetovej ekonomiky, nárastu cezhraničných transakcií a rozvoju medzinárodného obchodu. Medzinárodná administratívna spolupráca je realizovaná formou medzinárodnej výmeny daňových informácií, organizovaním simultánnych a multilaterálnych daňových kontrol, výmeny informácií týkajúcich sa praktických skúseností a postupov využívaných zahraničnými daňovými správami pri daňových kontrolách, odhal'ovaní daňových podvodov a v boji proti daňovým podvodom.

V roku 2005 útvarom zodpovedným za realizáciu medzinárodnej administratívnej spolupráce $v$ rámci daňovej správy Slovenskej republiky bolo oddelenie medzinárodnej administratívnej spolupráce (d’alej len „oddelenie MAS“). Po organizačných zmenách realizovaných na Daňovom riaditel'stve Slovenskej republiky (d'alej len „DR SR) oddelenie MAS bolo organizačne začlenené pod Kanceláriu generálnej riaditel'ky DR SR v rámci odboru medzinárodných vzt'ahov. Organizačná zmena nadobudla účinnost' 1.6.2005.

V oblasti dane z pridanej hodnoty (d'alej len „DPH“) bol rok 2005 prvým obdobím kedy sa medzinárodná výmena daňových informácií v SR realizovala počas celého kalendárneho roka.

\section{Právny rámec medzinárodnej administratívnej spolupráce}

V rámci EÚ medzinárodnú administratívu spoluprácu v oblasti DPH upravujú tieto právne normy:

- Smernica Rady 77/388/EHS (,6. smernica“),

- Smernica Rady 77/799/EHS, o vzájomnej spolupráci v oblasti priamych a nepriamych daní

- Nariadenie Rady 2003/1798/ES, ktoré v celom rozsahu nahrádza nariadenie 218/92/EHS, o administratívnej spolupráci v oblasti nepriamych daní (DPH) a je špecifickým predpisom pre oblast' DPH

\footnotetext{
* Ing. Pavel Kaštánek, Katedra spojov, Fakulta prevádzky a ekonomiky dopravy a spojov, Žilinská univerzita v Žiline, Univerzitná 1, 01026 Žilina, Slovenská republika, tel.: +421/41/5133100, fax: +421/41/5655615, e-mail: Pavel.Kastanek@fpedas.utc.sk
}

* Ing. Katarína Isteníková, Katedra spojov, Fakulta prevádzky a ekonomiky dopravy a spojov, Žilinská univerzita v Žiline, Univerzitná 1, 01026 Žilina, Slovenská republika, 


\section{Informačný systém VIES}

Za výmenu informácií o DPH (podl'a nariadenia 218/92/EHS) je zodpovedný Centrálny spojovací orgán (CLO). Elektronickú výmenu informácií uskutočňuje CLO prostredníctvom informačného systému VIES.

\section{Systém VIES umožňuje:}

1. platitel'om DPH overovat' platnost'IČ DPH svojich partnerov včlenských štátoch: na webovej stránke Európskej komisie. Webová stránka funguje na princípe overovania platnosti IČ DPH na základe informácií získaných z databáz jednotlivých členských krajín. Inak povedané, preverenie prebieha v databáze toho členského štátu, ktorého IČ DPH sa overuje. Niektoré časti systému môžu byt' $\mathrm{v}$ určitú dobu nefunkčné $\mathrm{z}$ dôvodu údržby a zabezpečovania dát databáz jednotlivých členských krajín. Jedná sa o známy problém a Komisia spolupracuje s členskými krajinami na zaistení minimálnej doby potrebnej pre aktualizáciu jednotlivých databáz.

2. daňovým orgánom overovat' platnost' IČ DPH a monitorovat' a kontrolovat' tok

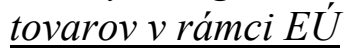

Všetky národné databázy členských štátov sú vzájomne prepojené komunikačnou siet'ou CCN (Common Communiction Network), prostredníctvom ktorej správca dane získava potrebné informácie z ostatných členských štátov, ku kontrole riadneho zdanenia transakcie. Údaje do tohto daňového systému sú získavané z:

- daňových priznaní

- súhrnných hlásení.

Členské štáty vytvorili efektívny systém elektronického uchovávania a prenosu údajov pre účely kontroly DPH. Je dostatočne flexibilný - dôkazom je, že sa od 1. 5. 2004 rozšíril o d’alších 10 štátov, medzi ktorými je aj Slovenská republika.

\section{VIES v SR}

Odo dňa pristúpenia Slovenskej republiky do Európskej únie bolo potrebné splnit' povinnost' spustenia informačného systému pre sledovanie intrakomunitárnych obchodov VIES. Informačný systém VIES bol budovaný v úzkej spolupráci s dodávatel'om v priebehu príprav Daňovej správy Slovenskej republiky na vstup do Európskej únie. V súčasnosti informačný systém VIES plní v reálnej prevádzke všetky funkcie stanovené Nariadením č. 1798/2003 o medzinárodnej administratívnej spolupráci v oblasti DPH.

Od 1. mája 2004 bola sprístupnená služba overovania identifikačných čísel DPH (IČ DPH) vydaných v iných členských štátoch EÚ. Samotné overovanie je určené tak pre daňové subjekty ako aj pre daňovú správu. O možnosti overenia IČ DPH je široká verejnost' pravidelne informovaná prostredníctvom masovokomunikačných prostriedkov. Služba overovania IČ DPH je určená pre daňové subjekty realizujúce dodania do iných členských štátov EÚ. Nasledovný graf obsahuje počty žiadostí o overenie IČ DPH prijatých oddelením MAS: 


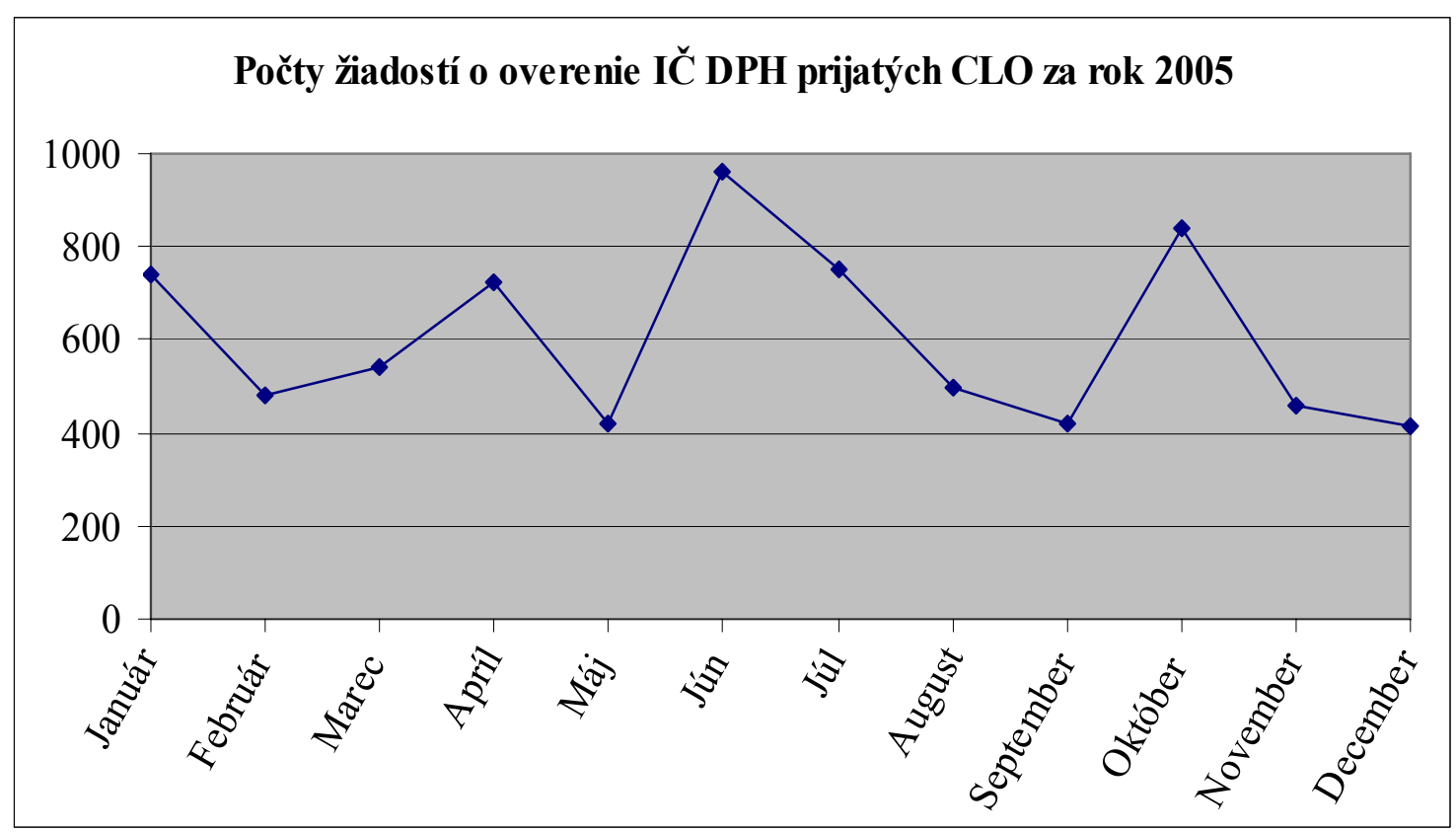

Graf znázorňuje počty overovaní IČ DPH prijatých oddelením MAS od slovenských subjektov. Neobsahuje počty overovania IČ DPH zamestnancami daňovej správy.

Súčasne odo dňa vstupu do Európskej únie bola stanovená nová povinnost' pre daňové subjekty - povinnost' podávat' súhrnné výkazy, ktoré obsahujú údaje o dodaniach tovarov osobám identifikovaných pre DPH do iných členských štátov v členení podla IČ DPH nadobúdatel'ov tovarov. Tieto súhrnné výkazy sú podávané štvrt'ročne a sú základným zdrojom informácií povinnej databázy pre systém VIES. Počty súhrnných výkazov za jednotlivé štvrt'roky sú znázornené v nasledovnej tabul'ke:

Tabul'ka : Počet súhrnných výkazov

\begin{tabular}{|c|c|}
\hline Štvrt'rok(rok 2005) & Počet riadnych súhrnných výkazov \\
\hline 1 & 10220 \\
\hline 2 & 11540 \\
\hline 3 & 11749 \\
\hline 4 & 12315 \\
\hline
\end{tabular}

Povinnost' podávat' súhrnné výkazy je stanovená v každom členskom štáte a tieto informácie sú následne predmetom výmeny prostredníctvom systému VIES - zozbierané súhrnné výkazy sa transformujú do presne stanovených súborov a ku koncu tretieho mesiaca po štvrt'roku, za ktorý sú podávané sa zašlú do všetkých členských štátov. V roku 2005 DR SR zaslalo všetky štvrt'ročné súbory do členských štátov EÚ v určenom termíne.

Prijaté údaje $\mathrm{z}$ iných členských štátov sú následne porovnávané s hodnotou nadobudnutí $\mathrm{v}$ daňových priznaniach podaných slovenskými daňovými subjektami. Tieto údaje by mali byt' zhodné. V prípade rozdielov sú tieto údaje podkladom pre miestne zist'ovanie, resp. daňovú kontrolu.

Je potrebné poznamenat', že nie $\mathrm{v}$ každom prípade rozdielu údajov o nadobudnutí z daňového priznania s nahlásenými údajmi zo systému VIES musí vždy íst' o vyhýbanie sa dani. Sú zrejmé príklady z praxe, kedy hlavne v období na prelome štvrt'rokov dochádza knepresnosti zaúčtovania dňa zdanitel'ného plnenia. Napr. slovenský nadobúdatel' nadobudnutie tovaru zaúčtuje 2.7.2005 (v tret'om štvrt'roku), ale zahraničný dodávatel' uvedie dodanie v súhrnnom výkaze za druhý štvrt'rok, čím vzniká samotný nesúlad. Z uvedeného 
dôvodu nie je možné použit' údaje $\mathrm{z}$ informačného systému VIES priamo na vyčíslenie daňovej povinnosti daňového subjektu. Údaje $z$ informačného systému VIES sú podkladovými údajmi, ktoré je nutné preverit' bud' u daňového subjektu, alebo prostredníctvom žiadosti do členského štátu EÚ.

Okrem pravidelne zasielaných informácií, ktoré sú zosumarizované za jednotlivé štáty, má daňový orgán prostredníctvom informačného systému VIES možnost' zistit' jednotlivých dodávatel'ov z iných členských štátov spolu s príslušnými hodnotami dodaní slovenským nadobúdatel'om.

Od spustenia systému VIES do reálnej prevádzky sú postupne zapracovávané d’alšie funkcie systému, ktoré nie sú stanovené Nariadením č. 1798/2003, ale ktoré posúvajú systém na vyššiu kvalitatívnu úroveň a umožňujú ul'ahčit' prácu užívatel'a pri zist'ovaní príslušných informácií.

Zároveň v rámci Európskou komisiou navrhnutej zmeny systému DPH (VIES 2) sa do VIES budú postupne zapracovávat' d'alšie komponenty, ktoré vyplývajú z navrhovaných legislatívnych úprav systému DPH. V rámci tohto projektu sa od 1.1.2007 začne sledovat' pohyb služieb, ktorý v súčasnosti vo VIES chýba. Bude tiež zapracovaná schéma „One-Stop Shop“, ktorá umožní zdanitel'nej osobe registrovat' sa len v jednom štáte a vykonávat' zdanitel'né transakcie v iných štátoch pod tým istým IČ DPH. Navrhuje sa, aby informačný systém VIES obsahoval aj d’alšie informácie, ktoré umožnia napr. sledovat' pohyb tovaru v rámci celej EÚ, čím VIES významne prispeje $\mathrm{k}$ identifikovaniu daňových podvodov.

Z uvedeného vyplýva, že informačný systém VIES nie je statickým, nemenným systémom, ale kvalitatívne sa posúva dopredu. Je potrebné aj nad'alej zdokonal'ovat' a aj investovat' do jeho vývoja, nakol'ko obsahuje dôležité informácie o obchodoch v rámci Európskej únie a v slovenskej daňovej správe nadobúda stále väčší význam v boji s daňovými podvodmi.

\section{Literatúra}

[1] ONDREÁŠOVÁ, Z.: Daň z pridanej hodnoty v praxi po vstupe do EÚ. Epos, Bratislava, 2005, ISBN 80-8057-637-8.

[2] Zákon č. 222/2004 Z.z. z 21. februára o dani z pridanej hodnoty.

[3] Portál daňovej správy. [online]. [s.a.]. Dostupné na: http://www.drsr.sk

[4] Interný materiál Daňového riaditel'stva Slovenskej republiky, 2005. 